\title{
A NINETEENTH-CENTURY WOMAN DIARIST $O R$ REBECCA OF GREEN BROOK FARM
}

\author{
BY JOYCE S. WAGNER
}

Ms. Wagner is a master's candidate in the English Department, Rutgers University

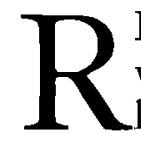

EBECCA WORDEN VAIL was a Quaker farm woman who died in 1872 and who, for a brief period in her life, January 30 to July 25, I 847 . It is possible that other diaries preceded this one, but it is fairly certain that none followed it. The pages following her last entry in the yellowed, fragile notebook are filled with household accounting entries for the next five years. This ledger-type conclusion to a book intended to hold personal thoughts somewhat devalues the preceding entries. It is almost as though she looked back on her six-months journal, found it wanting and decided to use the remaining pages for more practical and useful notations.

Was it a creative urge that led to the keeping of a diary in the first place? Or was it a desire to validate her life by recording it? Her entries are mundane, trivial and routine, unimaginative and uninspired, and yet the diary seen as a whole must be regarded as a creative outlet, a form of self-expression. It's not just the beautiful handwriting or the decorative embellishments (pointillism type dots surround her title, "Day Book for the Year I 847"), artistic expressions in themselves that make this diary a form of self-expression, but it is the kind of activities she records and her attitudes toward them. Although no personal thoughts, feelings or emotions are expressed, a picture of Rebecca Vail does finally emerge, although somewhat adumbrated, which allows one to make assumptions about her life and her role as a nineteenth-century farm wife. There are clues to her nature as much in what she does not say as in what she does. Her life was one of hard physical labor, as could be expected of a farm woman of the time, and her pleasures seem few. Perhaps writing in her diary at night was one; sewing appears to be another.

Since a diary by definition is written to oneself, there are no facts about her life mentioned, and, needless to say, she does not describe what is known to her. However, some biographical data has been 
gathered from other sources. She was married to a man named Emmor Vail, and they lived on a farm somewhere in or around Green Brook, New Jersey. She was probably around thirty years old when this diary was written. There are two children: Henry, an infant or toddler, and Lib or Elib, an older daughter of indeterminate age, maybe eight to ten. Relatives appear to have lived close by, as there are frequent visits to parents, uncles, aunts, etc. Putting names and relationships together is a problem in this type of research, since the knowledge is assumed by the writer of the diary.

By I 847 the industrial revolution was well underway in America, and in New Jersey railroads intersected most of the state. The sewing machine was invented in I 846 (although Rebecca Vail probably didn't have one), and factories were beginning to produce much of what had been produced in the home-clothes, home furnishings, tools. To a remote Quaker farm family however, used to selfsufficiency, the outside world of increased industry had very little effect. The Vails still produced most of their food and household needs and rarely left their home and family environs. It is uncertain what work the husband performed, but Rebecca Vail details the work she did. She made the family's clothes, mattresses, soap, coats, corsets. She churned her own butter, milked the cows, grew vegetables and fruits, raised chickens and cows for eggs and meat. She also baked, scrubbed, washed, painted, cooked, took care of the children and faithfully entered these accomplishments into a diary. Most of her diary entries begin and end the same way-stating the time of arising and the time of retiring. In between she briefly states the work done that day:

Feb. Ist Secont day (Monday-author) we ris at 5 in the morning and washed all day in the evening was tiered and went to bed at six o'clock all well ${ }^{\text {I }}$

Her week's work was routinized almost without deviation with certain chores being performed consistently on certain days. Monday was washday and nearly every "Second day" entry reads as above. Tuesdays consisted of ironing and folding clothes. Friday was always "fixin for bakeing" which presumably meant the mixing and kneading of dough, followed by baking on Saturday. What

All quotes are from the Rebecca Vail Diary from Rutgers University Special Collections. 
creative outlet could a woman who was bound to such heavy daily labor have? How did she express herself? It's hard to imagine a woman putting in an eight-hour day of washing clothes before noon, followed by an afternoon of housework and child care and still having anything left for herself. Rebecca seemed to be a dutiful woman who did the work expected of her. When she sat down in her spare moments to write in her diary, she most probably wrote of the activities which were important to her. Sewing in its many forms seemed to give her some satisfaction, if not pleasure, as evinced by the frequency of its mention:

"Jan. $307^{\text {th }}$ day ... was fixin for company in the fournoon and after noon doing suthern work ..."

"Suthern work" was coat-making. Mrs. Vail did this as a source of added income but she evidently derived a kind of artistic satisfaction from it:

". . . finished my coat and sent it to briant [a storekeeper?] at two and six ..."

"I got four coats to briants at two and sixpence A-peace";

". . . drove the cows out of the field and fed the chickons went back and worlked A while on my coats then came home and milked";

"Got up at five went to work and finished another coat and worlked the other";

"Went to plainfield and took my coats and got one dolar";

"Up at six cleared up and went to worlk on coats finished one coat and comenced another";

"churned in the four noon cushioned my lounge and ironed my coats ready to take home";

"took up my coats to briants and took up tenn pounds of butter and got twelve shiling and sixpence in cash."

There's a sense of satisfaction in these lines as though Rebecca is proud of the money she earns from things she herself produces. To fit in "suthern work" between chickens and cows is a nice contrast. One can almost picture this woman coming in from the barn, wiping her hands, eagerly working on her coats before returning to milk the cows. Another entry indicates reluctance to give up her coat making even when sick:

"third day arose at six in the morning and was quite sick had A violent pain acrost me but in the afternoon was better and worked on my coat."

It is curious that hardly any entry mentions the kind of food her 
family ate or the cooking she did. Perhaps cooking was not a creative act for her but another daily, necessary chore that she took little pleasure in. Nor does she mention her children or their activities on any daily basis. The housework and farmwork are not mentioned with the consistency that sewing is. Sewing, when not allotted its own time, seems to be fit in at odd times-Sunday mornings, late at night, between other chores:

"fifth day up at six all well . . I patched Emmors over coat darned three pare of stockings knit a little went to bed at 9";

"got up at six made a window curtain and knit";

"... up at four went to washing got dun at twelve went to sewing on cotton flanel shirts";

"up at six sewing on a shirt ....";

"up at five finished two shirts and worlked on another";

"up at five made A dish cloth, finished shirt, knit some";

"afternoon worked on a bed tick";

"darned stockings and worked on a shimmy";

"up at five went to worlk on my shimmy I finished my shimmey and Emmors busin";

"up at five cut out a corset and made it";

"cut out a frock for Henry";

"Eye finished henries frock and cut out mine";

"up at five went to worlk and made my dress . . . I cut out a pare of corsets";

"up at five patched and darned all day";

"up at five worlked on henries bonet and cloak cut out my white dress."

A hand-sewn article of clothing is in a sense a work of art, since it is created for a utilitarian purpose but with great care and talent. The pleasure Rebecca had in sewing was not only of creating something to be appreciated and used by others, but also the pleasure in exercising a talent, expressing herself through her sewing. Also it was work one could do sitting down.

"June 30 got my dress dun and put it on and went over to fathers and took tea." The work of art completed, it now had to be shown and praised ... . the artist's reward. Sewing perhaps did for her what other household chores did not; i.e. provide an outlet for her unarticulated need to create. Needle and fabric were her artist's tools.

Like sewing, the very writing of this diary was a creative act. 
Elaine Hedges likens keeping a diary to quilting and sewing as a parallel form of self-expression. By faithfully recording the drudgery of their lives, they are piecing together a portrait of the nineteenth-century woman. "From the entries in diaries, autobiographies and letters and from pieced quilts themselves, we are uncovering a strong tradition of industry, creativity and human expression that has been hidden too long.". The very words "patch," and "piece" are used in Rebecca's diary: "June 24 after noon went to Abram Vails to peace carpet rags." Also, recording these chores was a way of validating the worth of women's daily lives. If women were spending their lives in domestic toil, the recording of it somewhat justified these tasks which were not only taken for granted, but were not highly valued.

To Rebecca Vail and undoubtedly to other nineteenth-century women, the actual writing in a diary was another means of selfexpression. The handwriting in Vail's diary is exquisite. She formed her letters with care, making flourishes on capital letters. There is virtually no punctuation, her language is ungrammatical and the diary abounds with misspelled words, even her husband's name (Emmor, Emor). All of this contrasts with the elegant style of her handwriting. Since writing was not an approved nineteenth-century woman's pastime, it is not surprising that she did not know writing rules, punctuation and grammar. The various misspellings, though, are problematic, since Rebecca spells the same word correctly as many times as she spells it incorrectly. "I ironed" is later "Eye iyeroned" or "Iye made sope." "Rachel" is also "Ratchel," "Secont" is "second" "churned" is also "chirned," "corn, courn" and so on. A vague pattern emerges. When her handwriting is most artistic, these commonly used words take on new spellings. It is almost as if she's creating new spellings for the fun of creating. This is her book and she can control the spellings.

Toward the end of her diary, the handwriting becomes progressively worse until it is nearly illegible. This is difficult to account for. Either she ceased getting creative satisfaction out of the actual writing of the diary or she looked back over the sixmonths journal and found the entries of her daily activities meaningless. As mentioned earlier, the final pages of the book are ac-

2Elaine Hedges, Feminist Studies 8, no. 2, 198 I, p. 298. 
counting entries: "pare of shuse . . 0.75, 4 yds of muslin . . . 0.25 ," written in a sloppy, difficult to read hand. If the diary served as an artistic expression, of which neat handwriting was a requirement, listing of expenditures clearly did not have such a requisite.

Female relationships appear to be mainly family and relatives, as do most of her social relationships: "We had Sister Margaret, Brother Abram and Cuson Maria to tea." She was apparently much attached to her parents, as they visited each other almost daily, sometimes she spending the night there: ride";

". . . came to fathers ... stayed all night and took a sleigh

"Mother came over stayed a little while father came after her and they both stayed to tea."

In times of trouble it was the women who were relied on. During the winter her son Henry was ill, probably quite seriously. The strength, the support and the help in dealing with this illness devolved totally on the females in the family:

Feb. 5, "Henry was quite sick."

Feb. 6, "Mother came and stayed all day Henry no better. Went to bed at 9 but did not sleep much."

Feb. 7, "first day got up at five stayed home with Henry he was worse we did not go to meeting father and mother came we called the doctor Sarah sat up with him."

Feb. 8, "Henry not better mother here after noon mother went home and Sarah and Margaret came towards night mother came over again and Henry was worse We sent for Aunt Deborah and she came and put him in warm watter and he soon got better Aunt $\mathrm{D}$ and sarah stayed all night."

Feb. 9, "henry better Aunt D left Sarah stayed until towards night and then Aunt Sally called Mother came and the doctor came Mariah and Margaret sat up we went to bed until four in the morning."

Feb. Io, "the girls left and I stayed alone Henry keeps better Sarah and Margaret came and stayed all night we did not set up with him but was up several times."

The illness abated and life returned to normal with the listing of chores replacing comments on Henry's illness. The reliance on other women during this trauma is evident in the entries quoted. 
Aunt Deborah's treatment seems to be valued more than the doctor's. It was she who was called when things seemed desperate, and it was other women who sat up with Henry and took turns being there. The absence of any mention of her husband during this crisis is noteworthy.

Rebecca's diary lacks any expression of emotion, feelings, thoughts, desires. It is only by reading between the lines that we can even guess at her feelings and then only sparingly. When Henry was ill there is no outward expression of the fear and worry she must have been feeling. Yet in a line such as "Went to bed at 9 but did not sleep much" we can imagine a young mother lying awake worrying about her sick child. It is almost impossible in other places to determine what or how she was feeling.

Rebecca obviously had a strong sense of duty typical of the nineteenth-century woman. Her work and her duties to her family were put before any physical discomfort she had. There are several instances that indicate that she was ill or in pain but that the work still had to be done:

"I have a very bad cold being up nights";

"My cold keeps very bad."

Again, as in her son's illness, female relatives came to take care of Rebecca and her children while she was ill. There was not however, the luxury of idleness for her when sick, for the work still had to be done:

"Mother came and stayed a little while ... henry had a very hard criyeing spell I had a violent headache fixed for bakeing . . ."

"Up at six all well ackcept pain in my hips finished ironing sewed some and darned some";

"Up at five . . . my rist is quite lame went to work on my dress";

"Got up at five my head no better I quite sick . . I d dun my bakeing . . . eye went to bed after dinner was very sick."

"Up at four went to washing ... . went to work upstares was taken with the bowell complaint and did not get much done churned and foulded clothes."

The sheer physical endurance of this woman is impressive, but undoubtedly she is not atypical.

Reading a diary like this of an obscure nineteenth-century woman evokes a curiosity about the person, her life, her feelings. What kind of relationship did she have with her children, with her hus- 
band? Why did he seem like such a nonpresence in her life? What did she think about in her private moments? One wants to have more facts, a complete story, a plot and a denouement. Instead everything is left hanging. She died in 1872,25 years after she wrote this diary. All the questions about her existence will remain unanswered, just as other details of her personal life are lost; and yet, this brief glimpse into her life tells us at least something of what American farm life was like for women in 1847 . 